\title{
Negotiating Masculine Circles: Female Agency in Aphra Behn's Work
}

\author{
Arifa Ghani Rahman \\ Associate Professor, Department of English and Humanities, University of Liberal Arts \\ Bangladesh.ORCID: oooo-0003-1165-2541. Email: arifa.rahman@ulab.edu.bd
}

\begin{abstract}
In her works, Aphra Behn examines the possibilities of female agency in a patriarchal world. This paper begins by contextualizing Behn's work within the male literary tradition in which she wrote to understand the place of female agency. Her play The Rover is closely examined to show this agency in heterosexual relationships and its connection to money and parental/patriarchal authority. The paper also analyzes the interrelationship between subjects and objects of desire. The use of masks in the play as instruments that accord temporary liberation or empowerment is discussed, and the paper questions whether female agency in Behn's world is real or merely assumed. A poem is also examined to reinforce the conclusion which suggests that, despite empowerment in various forms, female agency is ultimately only temporary. However, the paper also questions whether Behn had ulterior motives in presenting female agency as unsustainable.
\end{abstract}

Keywords: Female agency, Empowerment, Objects of desire, Masks, Masculine

Aphra Behn became a controversial figure when she began writing for the stage and her writings have been the subject of much conjecture ever since. A woman extremely liberated for her age, Behn examines in her plays and poetry the possibilities of female agency in a male dominated world. The paper begins by contextualizing Behn within the literary tradition in which she wrote through an examination of Shakespeare's Venus and Adonis and Marlowe's Hero and Leander to show female agency in writings by her male contemporaries. Behn's play The Rover is then analyzed to show female agency in heterosexual relationships in relation to money and parental/patriarchal authority. The paper will look at the use of masks in the play as instruments that offer temporary liberation or empowerment, and will question whether female agency really existed in Behn's world; whether the power accorded the women is indeed empowering; whether they are agents of a free will; and to what extent their wielded power provides them with agency. To explicate this, The Rover will be examined in terms of the Girardian and the Sedgwickian triangle formed by the interrelationship between subjects and objects of desire. One of Behn's poems is also studied to further understand the issue of female agency in the author's work.

Historically, after Charles II was restored to the throne, England saw a revival of the theatrical arts. It also saw the entry of women into a world previously inhabited by men: women as playwrights, women as actresses, women as spectators. As Katherine Quinsey (1996) describes it, this was a period when the presence of women on and offstage resulted in the enactment of "a

(C) AesthetixMS 2020. This Open Access article is published under a Creative Commons Attribution Non-Commercial 4.o International License (http://creativecommons.org/licenses/by-nc/4.o/), which permits non-commercial re-use, distribution, and reproduction in any medium, provided the original work is properly cited. For citation use the DOI. For commercial re-use, please contact editor@rupkatha.com. 
deeply ambivalent engagement with questions of female subjectivity," thus, "greatly expanding speaking roles for women and playing almost obsessively on the presence of women in the theater" (p. 2). But this is not to say that prior to this time women's voices were silent. Katherine Philips, for instance, was certainly vocal about her feelings for her women friends in her poems. However, because she lived in Puritan times, Philips had to maintain a certain front to prevent disrepute. Although she adopted the conventional male poetic discourse of writing about samesex friendships, Philips made sure she maintained a "modest and feminine demeanor in court circles" and exhibited an "exemplary personal virtue" (Andreadis, 1989, p. 55), circulating her poems only within a private circle. She gave the appearance of being apologetic for daring to traverse a realm not open at the time to females. As such, her male contemporaries did not feel threatened, and rather admired her.

Aphra Behn, on the other hand, presented a stark contrast to Philips in her open declaration that she was writing for money and fame. After spying for Charles in Antwerp, in itself a daring enterprise for a woman of that time, she returned to England almost penniless, and even suffered a debtors' prison. According to her biographer, George Woodcock (1989), nothing is known after this until she emerged as a well-known literary figure two years later. Her entry into the theater coincided with the appearance of actresses on the stage but this did not alter the fact that she was entering a man's world. In other words, she had to contend with rivalry and jealousy from her male contemporaries. But, "in her struggles to overcome male prejudice and jealousy, [she] became a pioneer in the fight for women's emancipation” (Woodcock, 1989, p. 9).

Conventional writings tended to portray relationships where the male partner is the subject and the female counterpart the object of his desires. In her plays and poetry, however, Behn gives agency and a more active role to the female figure. Interestingly, such female agency can be found in Shakespeare's Venus and Adonis and Marlowe's Hero and Leander, and a brief look at these two poems is merited since they provide the unusual examples of the female as subject in works by men prior to Behn's time. In Venus and Adonis, Shakespeare inverts the traditional relationship of beloved-on-a-pedestal (female) and languishing-lover (male) to scornful beloved (male) and pursuant lover (female, goddess). He portrays an active and aggressive Venus, a true goddess, chasing a mortal, Adonis, who acts the part of the cold and distant beloved. So active does Shakespeare make Venus that, for most of the poem, it is her voice that is heard.

In Hero and Leander, Marlowe allows his heroine some degree of agency too. Compared to Venus's reactions to Adonis in Venus and Adonis, though, Hero is less overtly aggressive. She is not, however, the regular passive female of Petrarchan poetry, remaining neither cold nor distant during Leander's persuasion speech. She has, in fact, inspired him to speech by taking the initiative and coming "somewhat nere him" (Hero and Leander 1. 180) and startling him by this unexpected movement. Hero encourages Leander's advances while keeping up an appearance of coyness, so that she gains some control over the situation without making Leander feel threatened or emasculated. Marlowe adds a new dimension to Leander's character, however, by combining both the feminine and the masculine in him, which puts him in a position where he can be both active subject and passive object.

Female agency in both Shakespeare's and Marlowe's poems, however, is problematic. In Venus and Adonis, Venus's active role is so strong and aggressive that it alienates the object of her desire. The male figure seeks only to escape and the chase is thwarted in the end. In the case of Hero and Leander, as mentioned earlier, Leander is given a dual role - both masculine and feminine - which complicates the interpretation of his character. So, while the female characters 
appear stronger and more active, neither Shakespeare nor Marlowe is willing to yield complete power to them. This is where Behn steps in. Behn's women take care of themselves and each other. However, the agency of these women is achieved through the use of masks, which is examined particularly in this paper as it influences social relationships. The Rover is a case in point.

One of the things that Behn could not abide was forced marriages where a woman was subjected to the choices made by her male guardian. Her first play The Forc'd Marriage, focuses, as its name suggests, on this issue. In this play, she attempts to expose how marriages arranged by parents without their daughter's consent can ruin her life. The Rover, Behn's most successful play, also deals with this problem, but it goes a step further. Here, Behn gives agency to the female characters; that is, instead of making them the objects of desire as was the norm, she makes them the agents of desire and accords them mobility through the help of masks - convenient since the setting of the play is during the carnival time. Florinda's father has decided that she would marry the old Vincentio while her brother Don Pedro contrives to marry her to his friend Don Antonio. Florinda has no say in the matter although she is in love with Belvile. Thus, supported and encouraged by Hellena, her sister who is "an equally unwilling candidate for a nunnery" (Woodcock, 1989, p. 124), she sets out to obtain her love. Hellena too takes the opportunity to find herself a lover as does their cousin Valeria.

Throughout the play, Florinda formulates the plans by which Belvile and she might be united. Stepping out of the house without her brother's knowledge is her first step towards emancipation while the more active part she plays in bringing about the union with Belvile shows a reversal of the traditional roles. But in exchanging her passive female role for a more active masculine one, Florinda exposes herself, twice, to the danger of rape, a historically patriarchal tool of oppression. Significantly though, there is not one instance where her lover rescues her. She either does it herself or is assisted by her fellow females.

This issue of rape is deeply connected with the appearance of women on stage as Jean I. Marsden (1996) explains in her article "Rape, Voyeurism, and the Restoration Stage." The body of the actress is subjected to the male/audience's gaze so that "the rape becomes the physical manifestation of the desire perpetrated by the rapist but implicit in the audience's gaze. Thus the audience, like the rapist, 'enjoys' the actress, deriving its pleasure from the physical presence of the female body" (Marsden, 1996, p. 186). The presence of the female playwright evokes a similar response, as Catherine Gallagher (1993) argues, and publication of a woman's writings, in the seventeenth century, was equivalent to being a "public" woman; that is, the female playwright was a whore. In Behn's case, these ideas are manifest in her plays, as Alison Findlay (2010) states, particularly in Lucetta through whom "Behn characterises the common association between woman playwright, actress and whore” (p. 48).

In the first of the rape scenes in The Rover, Florinda is assaulted by Willmore who, in his drunken state, can only see a woman in the dark. He does not recognize her as his friend's beloved, or, generally speaking, as "belonging" to any man (in seventeenth century England, women were the property of first, the father or related male guardian, and then, the husband) which, to him, is reason enough to suppose she is a prostitute and, therefore, to be had/possessed. Dagny Boebel (1996) explains that "In the patriarchal system of signs, once she is loosed from her signification as Belvile's mistress, Florinda becomes a sign of generalized 'woman,' equated only with her biological essence, thus 'a very wench"' (p. 65). This interpretation is reinforced in the second rape scene where Blunt desires to avenge himself on womankind for his sufferings at the hand of Lucetta: 
... thou shalt lie with me too, not that I care for the enjoyment, but to let thee see I have ta'en deliberated malice to thee, and will be revenged on one whore for the sins of another" (Rover 4:5: 49-51).

To Blunt, thus, one woman is as good - or as bad - as the other. They blend into one form and become identity-less, their significance reduced to nothing. Florinda is also subjected to the threat of a gang rape when all the men, including her lover and her brother, draw swords - a very potent phallic symbol - to decide who will lie with her first.

Florinda had gained some independence by stepping out of the house in a mask, an opportunity accorded by the carnival, which also was a time of sexual license. The mask allows her to disguise herself to avoid detection as well as a chance to actively pursue her lover and test his faithfulness. For a while, she is the active agent of desire as she makes the plans and attempts to execute them. Having a fortune, Florinda need not be afraid to defy her brother, on whom she is not economically dependent. She is powerful enough to know what she wants and to pursue her goal. But, as Boebel (1996) says, in spite of such empowerment, "the assaults on Florinda silence her. She does not confront Belvile about his participation in the prospective gang rape, and she does not tell Hellena about Willmore's assault" (Boebel, 1996, p. 67). She seems to have absorbed the idea that since she was not actually harmed, there is no need for confrontation or punishment, which perhaps explains why Behn does not, in the end, show the men being punished or even made aware of having done wrong. According to Boebel (1996), though, Florinda becomes silent because "[s]he experiences a violent reassertion of phallic hierarchy and prerogatives" (p. 67).

Hellena, Florinda's sister, is, according to Heidi Hutner (1993), a combination of the virgin and the whore characters of Killigrew's play Thomaso, which was the source for Behn's play. In combining these two oppositional characteristics in the "sexually desirous yet virginal Hellena, Behn emphasizes the limited choices available to women of her age: the nunnery where female sexuality lies buried behind the monastery wall, or prostitution, in which female sexuality represents itself for male pleasure" (Hutner, 1993, p. 106). I would, however, add that there is a third alternative - that of marriage to the man of one's choice. Though marriage is yet another institution which threatens to bind and limit female existence, Behn in The Rover seems to suggest that if women choose their own partners, life would not be too bad.

The play begins with Hellena setting the tone for the active participation of the female characters in a pursuit commonly accorded to the male. She is daring enough too to defy her brother and voice her distaste of the system of marriage in that society. Hellena, however, falls in love with the Rover, Willmore, who does not believe in marriage, which, perhaps, should have been ideal in that she could be free of the bindings that accompany marriage. But since she has chosen this man herself, Hellena has the opportunity of being able to impose the bindings on the man and so, with wit and intelligence, she makes him finally succumb to her wishes. In her case, too, as she very carefully points out to her brother, inheritance of a fortune allows her to make her own choice without the threat of being disowned without a penny. It is an instance of the female empowerment that Jane Spencer (1995) mentions in her introduction to The Rover and Other Plays.

Compared to Florinda, Hellena is given more agency. Being not only beautiful but intelligent too, Hellena is able to take control of each of the situations in which she finds herself contending with her lover. The use of a mask and a disguise gives Hellena the opportunity to observe, without being subjected to scrutiny herself, the actions of the man she loves. In other 
words, the gaze, commonly masculine, is inverted. In her, as Julie Nash (1994) puts it, "Behn breaks out of the binary split that has fixed these other characters, [Angellica and Lucetta] and produced a heroine who occasionally controls both the gaze and her own pleasure, obtaining some form of subjectivity without resorting to cruelty or prostitution" (p. 83). By adopting the disguise of a man at one point, Hellena also adopts an assertive masculine role and finds a way to express her feelings directly to Willmore without seeming "improper." Hellena, as wit, is on a level with Willmore, but she gains the upper hand when she is able to extract a promise of constancy from the Rover and persuade him into marriage. As a woman with a fortune, she does not need to be financially dependent on Willmore, which makes the marriage seem a union between equals.

Angellica Bianca, who is, by all definitions, a whore, is Hellena's rival and a character who confuses all the norms of masculine society. She has the advantage of being in control of her body. It is she who actively engages the men's interest and names the price. The men have no choice but to pay what she asks. By having Angellica put up her picture and then look at the men looking at it, Behn, as Hutner (1993) notes, employs the "reversed double gaze - watching the men watch her" (p. 107). Angellica purposely submits herself to objectification, with an awareness of how the men will gaze on her. This awareness allows her a measure of control over the male gaze, which "is a means of acquiring subjectivity" (Nash, 1994, p. 81). Her assertive action, as Nash (1994) explains, taking her cue from Janet Todd, in hanging out her portrait and guiding/controlling the male gaze is "unfeminine" since it "places her too far in the realm of subjectivity, making her too powerful for her own good" (Nash, 1994, p. 82). Willmore, with whom Angellica unfortunately falls in love, feels threatened by her power and so does not return her feelings. Angellica's power is thus short-lived since Willmore betrays her. By falling in love with a man who does not reciprocate her feelings, Angellica takes on a role in which she can be dominated. In other words, she slips back into a more conventional feminine role at this point. This, however, could problematize Behn's own motives in writing Angellica's role, because, by making this character "incapable of achieving sexual-political conquest," she "facilitates her own conquest of the literary marketplace" (Smith, 2007, p. 5), thereby ensuring her place as a writer in the predominantly masculine literary circle.

Later on, though, Angellica attempts to avenge herself on Willmore. With a gun in her hand, Angellica assumes a masculine role, but she is unable to kill Willmore and is rather disempowered by having Antonio remove the gun from her hand and being led away. Willmore's nonchalant attitude towards her rage, too, serves to undermine her power. The whore Angellica is cast aside at this point to make way for the virgin Hellena. The issue of the success of one woman over another in gaining a man, however, is problematic in the sense that Angellica's failure may be attributed to her immoral life and Hellena's success to her virginity, virtues, and noble birth, factors or standards which have already been set by a masculine society. Once again, thus, the deciding agent becomes men which suggests that female empowerment is temporary.

For both Hellena and Angellica, Willmore is the object of desire. Both seek to appropriate his body. According to Eve Sedgwick (1985), in her interpretation of Rene Girard, this appropriation is a male action and the object of desire is usually a woman. In The Rover, the reverse occurs. Hellena and Angellica, two women, seek Willmore, a man. What is interesting about this relationship is that the triangle which this relationship forms does not point in one direction. It is a two-way interrelationship as shown by the diagram below: 


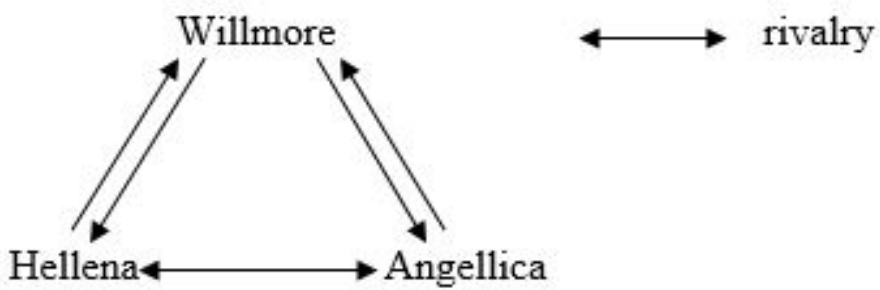

Fig.

$1:$

Two-way

interrelationship

Willmore subverts the triangle by making both Hellena and Angellica the objects of his desire. After playing on Angellica's emotions, he succeeds in making her betray the first rule of her trade - not to fall in love. Not only that, he symbolically appropriates her body when he tears her picture off the wall and later, cleverly induces her to sleep with him without payment. When she voices her love for him, he rejects her without ceremony. Willmore also turns the tables on Hellena's subjectivity when he discovers who she really is - an heiress. His vow of constancy to her, therefore, becomes dubious and Hellena's success in making him agree to marriage is undermined.

Hutner (1993) also explains how Willmore turns the gaze and becomes the subject in the triangle, instead of remaining the passive object of desire. When Hellena interrupts Willmore with Angellica, she appears in the guise of a page boy. Hutner (1993) says,

Willmore discovers the phallic disguise and turns it against her. He tells the jealous Angellica: 'This small Ambassador comes not from a Person of Quality, as you imagine, and he says; but from a very errant Gipsy, the talkingst, pratingst, cantingst little Animal thou ever saw'st. ... Thou may'st as well be jealous of thy Monkey, or Parrot as her' (4.2.353-57, 361-62). Notably, Willmore attempts to mislead Angellica as well as abuse Hellena - they are therefore doubly abused. The metaphorical implications of this passage are merely another means to disrupt the female character's act of self-assertion." (p. 108)

Willmore thus has fun at the expense of the two women who desire him and does not allow himself to remain in the passive position for long.

Another triangle formed within the complex relationships in this play is seen in the assertion of different forms of patriarchal authority over Hellena who is destined for the Church, an institution which substitutes for the parental authority of the home. On the other side, there is Don Pedro, her brother, who also represents patriarchal authority as her guardian at home. Hellena is unwilling to be subjected to either of these authorities but, nevertheless, she must accept, at least for some time, the united forces of the two. Because she must be a nun, she must comply with a certain code of conduct. Within the Church, her actions will be described by religious authority but while she remains outside the Church, Pedro will substitute for that authority. A relationship or connection is thus formed between Pedro and the Church - both masculine - whose object of interest is a woman.

Within the framework of the play, there are other triangles to be found. The collective gaze of the men directed towards Angellica's portrait may be considered one of those triangles where the men are interrelated in their desire for one common object. In a similar way, in the potential gang-rape scene, the men are united and the object of desire is Florinda. The 
relationships presented in the play, therefore, does not allow too much space for female agency, because, in the end, the women are stripped of the power they acquire temporarily.

As noted previously, the carnival setting of the play allows the use of disguises and masks which accords the women a certain amount of agency. They are able to assert themselves in ways they may not have been able to without the masks. The masks, therefore, provide them with the power to voice their opinions without the fear of censure. But "fear of censure" can automatically imply a more powerful agency which controls the movements of the female characters. The mask, in other words, only gives a false impression of empowerment. For one thing, the women are not themselves when they use the masks to hide their true faces. That is, before they can execute their agency in most cases, the women must shield their real selves from view because they are aware that they are crossing the boundaries of their patriarchally-constructed roles. Also, as pointed out by Ellen T. Goodson (2010), "The dangers of the chase and the play's tidy conclusion ... suggest at how ladies neither could nor should stray too far into the masculine roles of wooer and possessor." Thus, behind all feminine actions is the circumscription of masculine laws, and female agency is only a false or temporary empowerment.

In her poetry, however, Behn is more assertive about positive female agency than is evident in her plays. A brief examination of one of her poems will suffice to show the truth of this statement. "The Disappointment" is unusually explicit even for the libertine age in which Behn lived and tells of how a young woman, about to be penetrated by her lover, is left sexually frustrated when he loses his erection. The disappointment, however, is mutual. This is what the poem seems to talk about on the surface. But, as Arlene Stiebel (1992) argues, this is a very simplistic way of looking at the situation within the poem. In her opinion, what Lysander is about to do is rape Cloris whose denials are in earnest and are not the conventional "nos" which are taken to mean "yes."

Lysander loses his erection because Cloris stops struggling. According to Stiebel (1992), this is what makes Lysander lose his erection. Arousal here is dependent on the resistance struggle of the female. While this could be true, it does not allow for the fact that Cloris herself tries to rejuvenate Lysander's erection. On "returning from the Trance/Which Love and soft Desire had bred" [my italics to stress Cloris's equal agency as opposed to Stiebel's view], Cloris tries to discover why she has not been satisfied. The "snake" she finds disappoints her and her fleeing from the scene is an open declaration as well as an acknowledgment of that disappointment. Rather than quietly ignore the man's impotence as might be expected from the conventional female, Cloris actively leaves the scene. She is, significantly, compared to Venus who had also been the active agent in a heterosexual relationship. Female agency thus is displayed. However, according to Smith (2007), "The poem rejects Cloris as an autonomous sexual subject and, in Lysander's final curses, the poet shares Lysander's language in order to conclude the poem in a manner that excludes Cloris as author, speaker, and sexual subject" (21). Ultimately, therefore, by removing Cloris from the scene and, so undermining Cloris's agency, Behn's position as writer remains secure within the masculine literary circle.

Aphra Behn's unusual life had given her a perspective that did not apparently allow her to compromise or agree with the conventional norms of society as dictated by males. Being a woman writer who openly declared her commercial attitude towards her writing, she came to be attacked by her male contemporaries. As such, she had always had to defend her position as a writer. Money, thus, was an important consideration in how Behn portrayed her female characters. By ultimately showing, repeatedly, that female agency is unsustainable for the most part, Behn 
appears to subscribe to the existing social framework so that her own source of income is not threatened.

Behn's writings inspired other women to come forth with explicit and courageous pictures of female agency. Of these, Delariviere Manley is the best. As Jeslyn Medoff (1992) describes, Manley disregarded any interest in reputation and entered into associations which were considered dangerous for female writers - "theatre, political pamphleteering, journalism and scandal fiction" (p. 42). Her The New Atlantis landed her in jail which shows how much more explicit she was than Behn. However, Behn remains today a woman who dared traverse masculine circles and acquire a place of respect, simultaneously with disrepute for being too forward. And, as Woodcock (1989) puts it, Behn refrained from personal attacks and rather concentrated on exposing vices she thought needed reformation and "according to her conceptions she always strove for the individual's right to develop untrammelled by the interference of customs, creeds or moral censorship" (p. 229). But, at the end, one wonders if Behn may herself not have subscribed to the patriarchy to ensure her own survival as a writer by using a tongue-in-cheek approach in her writing: she portrayed female agency and satisfied her own instincts about female empowerment but ensured that the endings of her works, particularly, those discussed here, were satisfactory to the dominant masculine circle in which she wrote.

\section{References}

Andreadis, H. (1989, Autumn). The Sapphic-Platonics of Katherine Philips, 1632-1664. Signs: Journal of Women in Culture and Society 15(1), pp. 34-6o.

Behn, A. (1995). The Rover and Other Plays. J. Spencer (Ed.). Oxford: Oxford University Press.

Boebel, D. (1996). In the Carnival World of Adam's Garden: Roving and Rape in Behn's Rover. In K. M. Quinsey (Ed.), Broken Boundaries: Women and Feminism in Restoration Drama (pp. 54-70). Lexington, KY: University Press of Kentucky.

Findlay, A. (2010). Playing for All in the City: Women's Drama. Feminist Review, 96, pp. 41-57. JSTOR. Retrieved from http://www.jstor.org/stable/40928094

Gallagher, C. (1993). Who Was That Masked Woman? The Prostitute and the Playwright in the Comedies of Aphra Behn. In H. Hutner (Ed.). Rereading Aphra Behn: History, Theory, and Criticism (pp. 65-85). Charlottesville: University Press of Virginia.

Goodson, E. T. (2010). Aphra Behn's The Rover: Evaluating Women's Social and Sexual Options. Inquiries Journal/Student Pulse, 2(o7). Retrieved from http://www.inquiriesjournal.com/a?id=1695

Hutner, H. (1993). Revisioning the Female Body: Aphra Behn's The Rover, Parts I and II. In H. Hutner (Ed.). Rereading Aphra Behn: History, Theory, and Criticism (pp. 102-120). Charlottesville: University Press of Virginia, 1993.

Marlowe, C. (1972). Hero and Leander: A Facsimile of the First Edition, London, 1598. NY: Johnson Reprint Corporation and Washington, DC: The Folger Shakespeare Library.

Marsden, J. I. (1996). Rape, Voyeurism, and the Restoration Stage. In K. M. Quinsey (Ed.). Broken Boundaries: Women and Feminism in Restoration Drama (pp. 185-200). Lexington: University Press of Kentucky.

Medoff, J. (1992). The Daughters of Behn and the Problems of Reputation. In I. Grundy and S. Wiseman (Eds.). Women, Writing, History 1640-1740 (pp. 33-54). Athens: University of Georgia Press.

Nash, J. (1994, Fall). 'The sight on 't would beget a warm desire': Visual Pleasure in Aphra Behn's The Rover. Restoration: Studies in English Literary Culture, 1660-1700 18(2), pp. 77-87. 
Quinsey, K. M. (1996). Introduction. In K. M. Quinsey (Ed.). Broken Boundaries: Women and Feminism in Restoration Drama (pp. 1-10). Lexington: University Press of Kentucky.

Sedgwick, E. K. (1985). Between Men: English Literature and Male Homosocial Desire. NY: Columbia University Press.

Smith, E. (2007). Introduction: The Codification of Female Conquest in Women's Published Writing, 166o1769. In Triumphant Bodies: Sexual Political Conquest in Women's Published Writing, 1660-1763 (pp. 1-15). Cambridge Scholars Publishing, 2007. Google Books. Retrieved from https://books.google.com.bd/books?id=HmakBgAAQBAJ\&lpg=PA47\&dq=phallocentrism\%2oin\%20 aphra\%2obehn\&pg=PP1\#v=onepage\&q\&f=false

Smith, E. (2007). Fantastic Triumphs of Aphra Behn's Masculine Part in Poetry and Performance. In Triumphant Bodies: Sexual Political Conquest in Women's Published Writing, 166o-1763 (pp. 16-45). Newcastle, UK: Cambridge Scholars Publishing. Google Books. Retrieved from https://books.google.com.bd/books?id=HmakBgAAQBAJ\&lpg=PA47\&dq=phallocentrism\%2oin\%2o aphra\%2obehn\&pg=PPı\#v=onepage\&q\&f=false

Stiebel, A. (1992). Not Since Sappho: The Erotic in Poems of Katherine Philips and Aphra Behn. In C. J. Summers (Ed.). Homosexuality in Renaissance and Enlightenment England: Literary Representations in Historical Context (pp. 153-171). NY: Haworth Press.

Woodcock, G. (1989). The English Sappho. Montreal: Black Rose Books. 